\title{
A RARE COMPLICATION AFTER REPAIRING TEMPORAL LOBE HERNIATION INTO MASTOID CAVITY: NON-CONVULSIVE STATUS EPILEPTICUS
}

\author{
ORTA KULAK MASTOID KAVITEYE UZANMIŞ TEMPORAL LOB HERNIASYON \\ ONARIMI SONRASI NADIR BIR KOMPLIKASYON: NONKONVULZIF STATUS \\ EPILEPTIKUS
}

\author{
Mehmet ÇELİ*, Kadir Serkan ORHAN*, Elif Kocasoy ORHAN*, Burak KARABULUT*, \\ Candan GÜRSES*, İsmet ASLAN*
}

\begin{abstract}
The aim of this study is to present the case of an 18-year-old male who developed non-convulsive status epilepticus (NCSE) after the operation for temporal lobe herniation. The herniation of meningeal and brain tissues into the middle ear and mastoid cavity is a rare and potentially life-threatening condition. Temporal lobe herniation might occur after otologic surgeries which are often related with an iatrogenic bony defect of tegmen tympani. NCSE can be defined as prolonged seizure activity and is an extremely rare complication of otological surgeries. To our knowledge, this is the first case for NCSE which developed after otologic surgery in the literature.

Keywords: Herniation; mastoidectomy; mastoid cavity; temporal lobe; status epilepticus; nonconculsive; tegmen tympani
\end{abstract}

\section{ÖZET}

Bu çalışmada amaç 18 yaşında temporal lob herniasyon onarımı sonrası nonkonvulzif status epileptikus (NKSE) gelişmiş olguyu takdim etmektir. Orta kulak mastoid kaviteye herniye olmuş meningeal ve beyin dokusu seyrek görülen ve hayati tehdit eden bir durumdur. Temporal lob herniasyonu otolojik cerrahilerden sonra meydana gelebilir ve sıklıkla tegmen timpanide iatrojenik kemik defekti oluşturulması ile ilişkilidir. NKSE uzamış nöbet aktivasyonu şeklinde tanımlanabilir ve otolojik cerrahilerden sonra nadir bir komplikasyondur. Bu çalışma bizim bilgimize göre otolojik cerrahi sonrası gelişen NKSE açısından literatürdeki ilk olgudur.

Anahtar kelimeler: nonkonvuzif; status epileptikus; heniasyon; temporal lob; tegmen timpani; mastoidektomi; mastoid kavite

\section{INTRODUCTION}

The incidence of temporal lobe herniation after otological surgery is not known. The causes of temporal lobe herniation of cranial contents are congenital, neoplastic, infectious and most frequently, traumatic (1). Mastoidectomy can be performed for a variety of indications including acute and chronic infections of the middle ear and mastoid (30\%), cholesteatoma (50\%), different tumors of the temporal bone, as well as when there is access for facial nerve surgery, cochlear implantation, closure of cerebrospinal fluid (CSF) leakage and a need to reach the internal auditory canal and the skull base (2). Intracranial complications of otologic surgery are rarely in the form of seizures, but in our case of an 18-year-old male, non-convulsive status epilepticus (NCSE) was seen following the operation for temporal lobe herniation due to iatrogenic bony

\footnotetext{
Date received/Dergiye geldiği tarih: 23.06.2015 - Date accepted/Dergiye kabul edildiği tarih: 04.05.2016

* İstanbul University, İstanbul Faculty of Medicine, Department of Otolaryngology, Head and Neck Surgery, İstanbul TURKEY

(Corresponding author/İletişim kurulacak yazar: mehmetcelik@istanbul.edu.tr)
} 
defect. This is the first case of NCSE that occurs as a consequence of mastoidectomy in literature.

\section{CASE REPORT}

An 18-year-old male patient was admitted to our clinic with ear discharges since his childhood. He had an ear operation on his right side three years ago. One year later following the operation, a second surgery had been performed for the recurrent chronic otitis media in the same clinic. Although, second operation had been performed, ear discharge had not stopped. Afterwards, he was referred to our tertiary clinic because of persistent symptoms. His physical examination revealed that central perforation was on the left ear drum and subtotal perforation with attic retraction was on the right side. The right middle ear mucosa was hypertrophic. Pure tone audiogram revealed a $45 \mathrm{~dB}$ mixed type hearing loss on both sides. Soft tissue density in middle ear cavity was observed bilaterally in his temporal bone high resolution computed tomography (CT). In assessment of CT scans, there was a 7-8 $\mathrm{mm}$ bone defect at the tegmen tympani region as well as a temporal lobe herniation to the mastoid cavity on the right side (Figure $1 \mathrm{a}, \mathrm{b})$. Otorrhea was not detected in beta-2 transferrin assay. Under general anesthesia, operation was started with retroauricular "C" shape incision via previous operation scar. Following retroauricular flap elevation; in mastoid cavity, the herniation of temporal lobe (size of herniation was $1 \mathrm{~cm}$ ) and granulation tissue were exposed. After the excision of the pathologic tissue, herniated portion of the temporal lobe was pushed slightly up to tegmen and the defect of the tegmen bone was repaired with tragal cartilage and temporalis fascia graft. In addition, canal wall down mastoidectomy was performed for the retraction pocket and the epithelium in the attic area.
There was no complication in the intraoperative period. At the 20th hour following the surgery, he felt nausea, vomited and returned to bed after washing his face and hands. He had no memory of what followed. His vital signs including body temperature were normal. After a period of unconsciousness, he had a generalized tonic clonic seizure for approximately 5 minutes. Although the convulsion stopped, unconsciousness persisted. He recovered his consciousness in 6 hours, 4 of which he could not remember at all while he could vaguely remember the last 2 hours. He was diagnosed as "nonconvulsive status epilepticus". The mental status of the patient did not improve with $5 \mathrm{mg}$ intravenous diazepam, and then the patient was given $1000 \mathrm{mg}$ diphenylhydantoin (PHT) intravenously. After PHT, he regained consciousness and his neurological examination was normal and no otorrhea was seen. Cranial CT was performed as soon as possible and there was no pathology requiring emergent intervention (Figure 2). Intensive care was not necessary since his symptoms disappeared with antiepileptic medication. It was decided to follow the patient with carbamazepine. On the third day after the seizure, as soon as routine EEG unit was available, his EEG was taken, which showed a slight disorganisation during hyperventilation in the right temporal lobe region. On the 5th day, magnetic resonance imaging (MRI) revealed a bleeding focus in the right temporal region but it was not considered an emergency situation by our neurosurgeon. EEG examination which was performed in the second week showed mild disorganisation of the right temporal region similar to the first examination. The patient was discharged in the $2^{\text {nd }}$ week after the surgery without any additional problems. EEG examination was normal in the 6th month after the seizure. There was no additional problem in the first follow up year.
Figure a.

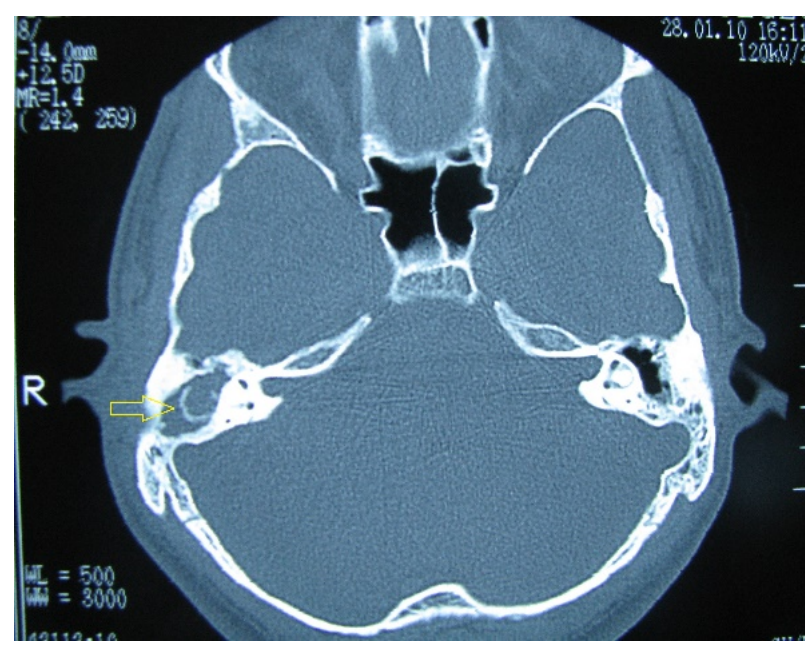

Figure b.

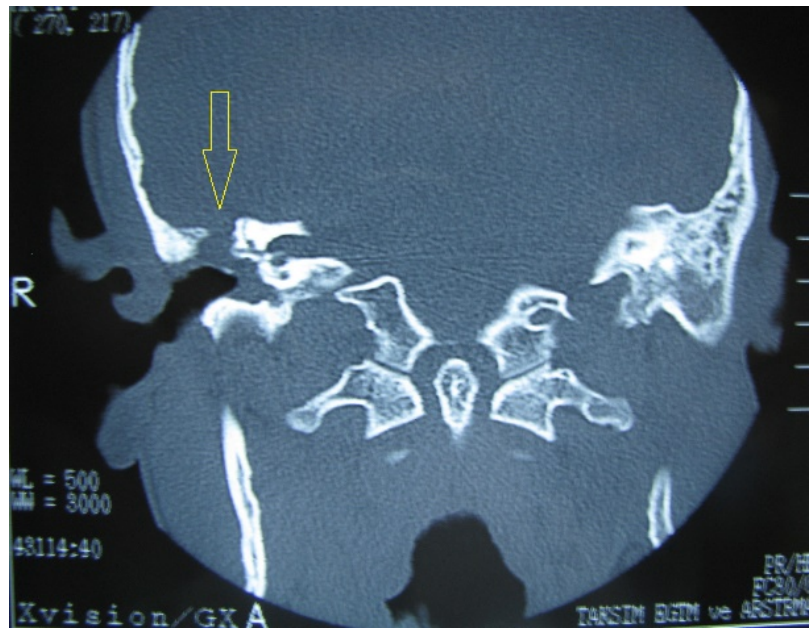

Figure 1. (a): Preoperative axial plan CT shows a soft tissue in the mastoid cavity (arrow). (b): Coronal plane CT shows the tegmen defect (arrows) 


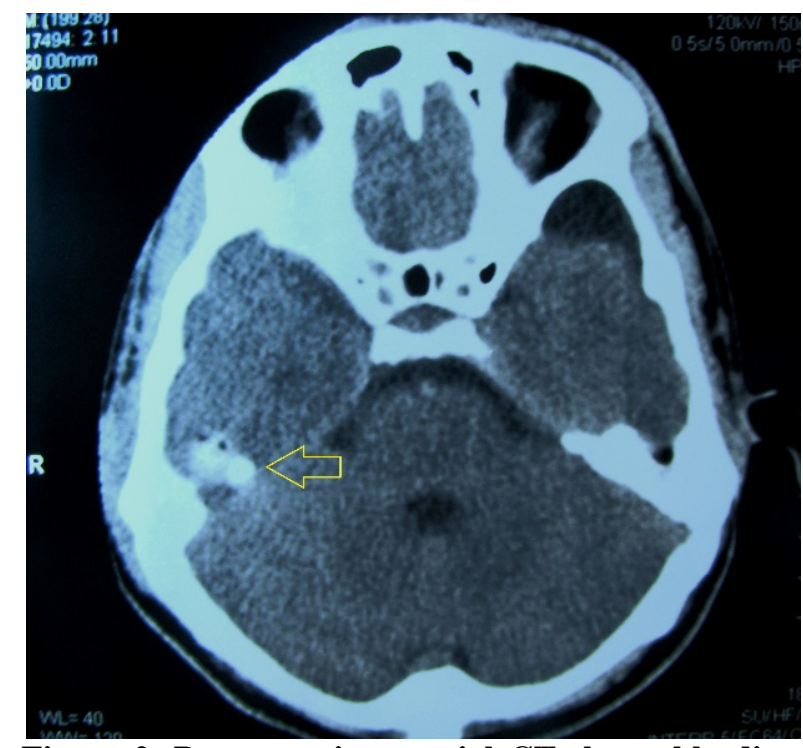

Figure 2. Postoperative cranial CT shows bleeding focus in the temporal lobe (arrow).

\section{DISCUSSION}

In temporal lobe herniation, $86 \%$ of the patients with brain herniation are reported to have chronic otitis media with or without cholesteatoma, and $77 \%$ of them underwent one or more mastoid surgery (1). The bony defect, which results from either surgery or infection, is the most important factor for brain herniation. Some authors believed that bony defects are not the only reason for brain herniation, but a dural defect is also needed $(3,4)$. There are many theories for the pathogenesis of dural injury: local ischemia due to compression of large cholesteatoma, dural destruction by enzymatic proteins secreted by cholesteatoma, inflammatory damage by granulation tissue and the iatrogenic injury $(1,3,5,6)$.

Temporal lobe herniation may cause intracranial complications such as seizures and infections like meningitis or brain abscess. Therefore, to prevent these complications, patients with herniation should be treated surgically as soon as possible. Surgical treatment can be performed with transmastoid approach, middle cranial fossa approach or a combination of these $(1,3,7)$. Small defects can be repaired with transmastoid approach, while the middle cranial fossa approach is recommended for larger defects. In their series of 38 patients, Jackson et al. reported that middle cranial fossa approach was used in 4 of the patients, transmastoid approach in 15 patients and combined approach in 19. In 10 of the patients, postoperative complications such as sensorineural hearing loss in 4 patients, epileptic seizures in 3, cerebrospinal fluid leak in 2, stroke in 2, sepsis in 1 and proplast extrusion in 1 were observed (1). However there is no detail about the type and the duration of seizures. It is not stated whether otorrhea occurred with sepsis in the same patients who had seizures. Mosnier et al. reported no postoperative complications in 15 patients who were treated with the combined approach (5). In the 12-patient series of Wooten et al, 7 of them were operated with transmastoid and 5 with combined approach. Cerebrospinal fluid leak was found after the surgery in 2 patients (7).
The etiology of NCSE in our patient was probably the hemorrhage in temporal lobe. He did not have either otorrhea or fever. Receiving general anesthesia (atracurium besylate, fentanyl citrate, sevoflurane, propofol) and using prophylactic antibiotics before the operation (ceftriaxone) are ruled out as factors leading to NCSE. Postoperative hemorrhage in temporal lobe is shown as a mild injury and no other cause but mild hemorrhage in the temporal lobe was determined to be the only reason of NCSE in our patient. Since MR is more sensitive than CT, CT taken after the operation did not show the minor hemorrhage.

Our case highlights the importance of considering NCSE for the differential diagnosis of any patient with altered mental status. Only NCSE without any motor components is frequently misdiagnosed or diagnosed belatedly. NCSE may occur in patients with diverse clinical diagnoses such as hypoxic-anoxic encephalopathy, cancer, autoimmune disorders, drug toxicity, pregnancy, infections, alcohol intoxication/ withdrawal, central nervous system lesions, electroconvulsive therapy, chromosomal alterations, peritoneal dialysis, cerebral hamartomas, following general anesthesia or head trauma. Due to the heterogeneity of its clinical symptomatology, NCSE is often missed and generally underdiagnosed (8). After an emergent treatment of NCSE, the etiology should be investigated to eliminate further problems. The presence of probably secondary generalized tonic clonic convulsion made it possible to detect NCSE in our case.

\section{REFERENCES}

1. Jackson CG, Pappas DG Jr, Manolidis S, et al. Brain herniation into the middle ear and mastoid: concepts in diagnosis and surgical management. Am J Otol 1997;18:198-206.

2. Migirov L, Eyal A, Kronenberg J:Intracranial Complications following Mastoidectomy. Pediatric Neurosurgery 2004;40:226-9

3. Sanna M, Fois P, Russo A, Falcioni M. Management of meningoencephalic herniation of the temporal bone: Personal experience and literature review. Laryngoscope 2009;119(8):1579-85.

4. Neely JG, Kuhn JR. Diagnosis and treatment of iatrogenic cerebrospinal fluid leak and brain herniation during or following mastoidectomy. Laryngoscope 1985;95:1299-300.

5. Mosnier I, Fiky LEL, Shahidi A, Sterkers O. Brain herniation and chronic otitis media: diagnosis and surgical management. Clin Otolaryngol 2000;25:385-91.

6. Glasscock ME III, Dickins JR, Jackson CG, et al. Surgical management of brain tissue herniation into the middle ear and mastoid. Laryngoscope 1979;89:1743-54

7. Wotten CT, Kaylie DM, Warren FM, Jackson CG. Management of brain herniation and cerebrospinal fluid leak in revision chronic ear surgery. Laryngoscope 2005;115:1256-61.

8. Maganti R, Gerber P, Drees C, Chung S. Nonconvulsive status epilepticus. Epilepsy Behav 2008;12(4):572-86. 